\title{
Effect of Sun Dried, Dehulled and Boiled Kidney beans on Hematological and Serum Biochemistry of Broiler Chickens
}

\author{
J. C. Okonkwo ${ }^{1}$, J. I. Umegwuagu², I. F. Okonkwo², D. N. Onunkwo, ${ }^{3, *}$ \\ ${ }^{1}$ Department of Animal Science and Technology, Nnamdi Azikiwe University, Awka, Nigeria. \\ ${ }^{2}$ Department of Microbiology and Brewery,Nnamdi Azikiwe University, Awka, Nigeria. \\ ${ }^{3}$ College of Animal Science and Animal Production, Michael Okpara University of Agriculture, Umudike, Abia State. \\ *Corresponding Address
}

\begin{abstract}
A four-week feeding trial was conducted to assess the effect of sun dried (raw) (SD), dehulled (D) and boiled kidney beans (BKB)on the haematological and serum biochemistry of broiler birds. One hundred and twenty unsexed broiler birds were used for the study. The birds were randomly assigned to four dietary treatments replicated three (3) times with twelve (12) birds per replicate in a completely randomized design (CRD). The treatment groups were control diet $(C D)$, sun dried kidney bean (SDKB), dehulled kidney bean (DKB) and boiled kidney bean (BKB), designated as T1,T2, T3 and T4, respectively. The feeding trial lasted for four weeks. The proximate composition of the kidney beans used was also determined. The proximate composition obtained showed that kidney beans is a good protein source for birds (crude protein content of $20.98 \%$ ). At the end of the feeding trial, blood samples were collected and the haematological and serum biochemical parameters of the birds were determined using standard methods. Generally, the diets used exhibited significant effects on both the haematological and serum biochemical parameters of the birds studied. Diet without kidney bean (Control) and diet containing sun dried kidney bean gave the best result, though all the haematological and biochemical values obtained in the studyfall within the referral range indicating that processing method had no negative effect on the haematological and serum biochemical parameters of the birds. Based on the findings in this study, it was recommended that kidney bean is a good source of plant protein in animal diet and does not necessarily need to be processed prior to its incorporation in animal feed.
\end{abstract}

Keywords-Sun dried, dehulled, boiled kidney beans, haematology, serum biochemistry, broiler birds.

\section{INTRODUCTION}

Feedstuff such as fishmeal and soybean are valuable components of poultry diets because of their high protein content and amino acid profile. However, current trends in the diversified use of these known protein sources both in industry and as human food have increased their market values. Therefore, identification, development, and utilization of potential alternatives are imperative for the sustainability of poultry industry. One of such alternatives is the kidney bean which is a legume plant protein source. Kidney bean has not gained widespread industrial, economic and nutritional importance because its acceptability and utilization has been limited (Ofongo et al., 2007).

Kidney bean (Phaseolus vulgaris) is one of the neglected beans among the tropical legumes. It is a herbaceous annual plant. It is an excellent source of vegetable protein, starch, soluble and insoluble fiber, vitamins (especially the B group) and minerals (particularly potassium, Iron, Zinc, Magnesium and Manganese), but very low in fat content (Enneking, 2011). It can be used to fortify cerealbased diets especially in developing countries because of its high protein content (Hussein et al., 2015).It is also a rich source of vitamin, minerals and relatively high in crude fibre. Kidney bean is one such protein source which when used in the fortification or enrichment of cereal based diets could go a long way in improving their nutritional status. An important aim of research in animal production is to enhance livestock production while providing adequate animal protein and livestock byproducts for human consumption. Kidney beans are mainly composed of carbs and fibre but are good and rich source of protein. Although the nutritional quality of bean plant protein is lower than animal protein, beans are an affordable alternative for many people in developing countries. In virtue of its amino acid constituent, kidney bean plays a significant role in the growth, egg 
production, immunity, adaptation to the environment and in many other biological functions. Optimization of its protein supply requires a thorough understanding of the protein requirement of the birds and manipulation of the protein supply to suit various environmental conditions and health status of birds. Research reports showed that it possess excellent nutritional profile with $22.7 \%$ protein, $3.5 \%$ mineral $1 \%$ fat and $57.7 \%$ carbohydrates, out of which, total carbohydrate have $38.6 \%$ starch and $18.8 \%$ dietary fibre $(60 \%$ insoluble and $40 \%$ soluble). Its protein has high lysine content of about 5\% (Marzoet al., 2002; Mustaphaet al., 2016).

Proteins mostly found in these beans are storage proteins, that is, 75-80. Because kidney bean is an excellent source of lysine, it can be used for the fortification of cereal based diets (Loggerenberg, 2007). He maintained that it is the best source of vitamin $\mathrm{B}$ series and essential minerals like $\mathrm{K}, \mathrm{Ca}, \mathrm{Mg}, \mathrm{P}$ and $\mathrm{Fe}$.

\section{MATERIALS AND METHODS}

Study site

The experiment was carried out at the poultry unit of the Department of Animal Science Teaching and Research Farm, Nnamdi Azikiwe University, Awka, Anambra State. The farm is located behind the works Department off the road connecting to the East gate of the University, with an annual mean temperature and rainfall of about $34^{\circ} \mathrm{C}$ and $1500 \mathrm{~mm}$, respectively. It lies within the latitude of $6^{0} 15^{\prime} 10^{\prime \prime} \mathrm{N}$ and $7^{0} 08^{\prime} 31.9^{\prime}$ 'E, according toObikaonu et al.(2011)

\section{Procurement of the Kidney bean and experimental birds}

The kidney beans that were used for the experiment were sourced from the Eke Awka market in Awka, Anambra State. One hundred and twenty day old broiler birds of the Arbo acre strain were procured from Fidan hatchery in Ibadan, Oyo state.

\section{Processing of the experimental material}

The kidney beans that were used were sorted out to remove dirt (including stones, dust, etc.), weighed and then subjected to different processing methods (Treatments):

a) Sun dried kidney beans: After removing the dirt and weighing, the seeds were ground.

b) Dehulled kidney beans: The sorted and weighed seeds were soaked in cold water for 18-24 hours. The seed coat was then removed with the aid of a grinding machine (decorticated).The beans were separated from the coat manually after the dehulling operation. They were oven dried at $85^{\circ}$ and later on sun dried for four days before been ground.

c) Boiled kidney beans: The sorted and weighed seeds were poured into a cooking pot containing

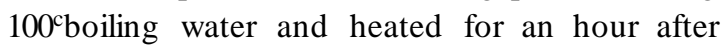
which the water was drained out and the seeds obtained were oven dried at $85^{\circ} \mathrm{C}$ and later on sun dried for four days before grinding.

\section{Formulation of the experimental diet.}

Four (4) experimental diets were formulated as shown in Table 1. Treatment 1 (T1) contained no Kidney beans and as such, served as the control diet. T2, T3, and T4 contained $10 \%$ each of sun dried (raw) kidney bean, dehulled kidney bean and boiled kidney beans, respectively. The feed ingredients used for the formulation of the various experimental diets were all procured from Palmark Agro Ventures and Bonitas Agro Ventures, both of which are located at Afor Nnobi market in Nnobi, Idemili South Local Government Area of Anambra State.Calculated chemical composition of the broiler starter diet of the experimental diets is shown in Table 2, while Table 3 showed the Proximate composition of the sun dried, dehulled, and boiled kidney beans.

Table.1.Composition of the starter diet fed to the birds

\begin{tabular}{lllll}
\hline Ingredients & TI $(0 \%)$ & T2 $(10 \%)$ & T3 (10\%) & T4 (10\%) \\
\hline Maize & 50.50 & 47.00 & 47.00 & 47.00 \\
Soybean & 21.00 & 21.00 & 21.00 & 21.00 \\
Fishmeal & 3.50 & 4.00 & 4.00 & 4.00 \\
KBM & ----- & 10.00 & 10.00 & 10.00 \\
Wheal offal & 4.00 & 4.00 & 4.00 & 4.00 \\
PKC & 6.75 & 4.00 & 3.75 & 4.00 \\
GNC & 10.00 & 5.75 & 6.00 & 5.75 \\
Bone meal & 3.00 & 3.00 & 3.00 & 3.00 \\
Lysine & 0.25 & 0.25 & 0.25 & 0.25 \\
Methionine & 0.50 & 0.50 & 0.50 & 0.50 \\
Vitamin premix & 0.25 & 0.25 & 0.25 & 0.25 \\
Salt & 0.25 & 0.25 & 0.25 & 0.25 \\
\hline Total $(\mathrm{kg})$ & 100.00 & 100.00 & 100.00 & 100.00 \\
\hline
\end{tabular}




\begin{tabular}{|c|c|c|c|c|}
\hline $\mathrm{CP}(\%)$ & 22.02 & 21.90 & 21.94 & 21.90 \\
\hline $\mathrm{CF}(\%)$ & 4.30 & 4.36 & 4.34 & 4.36 \\
\hline Cal Energy & 2979.70 & 2949.07 & 2948.63 & 2949.07 \\
\hline
\end{tabular}

Table.3.Proximate composition of the sun dried, dehulled, and boiled kidney beans.

\begin{tabular}{llll}
\hline Proximate Fractions & $\begin{array}{l}\text { Sun dried(raw) } \\
\text { kidney bean }\end{array}$ & $\begin{array}{l}\text { Dehulled kidney } \\
\text { bean }\end{array}$ & Boiled kidney bean \\
\hline Moisture content (\%) & 8.69 & 13.47 & 9.99 \\
Ash (\%) & 3.78 & 3.47 & 3.40 \\
Crude protein (\%) & 20.98 & 21.00 & 19.21 \\
Ether extract (\%) & 1.60 & 1.80 & 1.85 \\
Nitrogen free extract (\%) & 58.45 & 56.79 & 58.38 \\
Dry matter (\%) & 91.31 & 86.53 & 90.01 \\
Crude fiber (\%) & 6.50 & 3.00 & 7.20 \\
ME kcal/g & 3553.54 & 3252.01 & 3515.56 \\
\hline
\end{tabular}

Design of the experiment and housing of the experimental birds

The experiment was conducted using a Completely Randomized Design (CRD) with four dietary treatments. The model employed was:

$\mathrm{Xij}=\mu+\mathrm{Ti}+£ \mathrm{ij}$

Where:

$\mathrm{Xij}=$ Observation made on $\mathrm{i}^{\text {th }}$ treatment (haematological or biochemical indices) arising as a result of:

$\mu=$ Population mean

$\mathrm{Ti}=$ Treatment effect

$£ \mathrm{ij}=$ Experimental error

Each treatment had 30 birds which were assigned into three different groups of 10 each (replicates). The experiment lasted for four (4) weeks.

\section{Management of the experimental animal}

120 unsexed four weeks old commercial broiler birds of the Arbor acre strain were procured from Fidan hatchery located at Ibadan and used for the experiment. The chicks were given a solution of sugar and milk in water on arrival as an anti-stress. The birds were acclimatized for one week; thereafter they were randomly allocated to the four dietary treatments. During the period of the experiment, feed and water were given ad libitum. Vaccination programs were carried out as required. Other routine poultry management activities such as washing of drinkers, cleaning of the experimental house and changing of the litters were strictly observed.

Collection and preparation of blood samples for haematological and serum biochemical tests

At the end of the fourth week, the haematological and serum biochemical indices of the birds were determined.
Blood samples were collected by bleeding the wing with the use of $2 \mathrm{ml}$ syringe and needle set. For haematological test, the blood samples were collected into universal bottles containing EDTA (Ethylene diamine tetra-acetic acid). Samples for biochemical test were collected into another set of universal bottles without EDTA. All blood samples collected were immediately placed in a flask containing ice cubes to prevent haemolysis. The samples for serum were centrifuged at $300 \mathrm{rpm}$ for I0 minutes to obtain the serum and kept frozen $\left(-4^{\circ \mathrm{c}}\right)$ until required for analysis.

Determination of haematological and serum biochemical indices of the birds.

The haemoglobin content $(\mathrm{Hb})$ was determined using Sahil's method, white blood cell (WBC) by Neubauers method and red blood cell (RBC) by the use of formal citrate solution. The values obtained for $\mathrm{RBC}, \mathrm{Hb}$ and PCV were used to calculate the mean corpuscular volume (MCV) and mean corpuscular haemoglobin concentration(MCHC).

Serum cholesterol, AST and ALT were determined using the Randox diagnostic kit. Creatinine (Calorimetric method),Urea (Berthelot method), Total protein (Biuret's method), Globulin (Kjeldahl's method), Glucose (GOD POD method) and Albumin (Photometric method).

\section{Statistical analysis}

The data collected were subjected to analysis of variance (ANOVA) using statistical software (SPSS 20) and the differences between treatment means were separated using Duncan Multiple range test (DNMRT) at5\% $\alpha$ level. 


\section{RESULTS AND DISCUSSION}

\section{Haematology indices}

There were significant $(\mathrm{p}<0.05)$ variations in the blood cellular constituents of birds fed control diet (CD), sun dried kidney bean (SDKB), dehulled kidney bean (DKB) and boiled kidney bean (BKB) based diets (Table 4). Birds maintained in SDKB based diet (T2) had the highest $\mathrm{Hb}$ value, followed by those in the control diet (CD), while those in boiled $\mathrm{KB}$ (BKB) had the least. RBC was highest in birds raised with control diet, followed by those in SD based diet and least in those BKB. PCV, $\mathrm{MCV}, \mathrm{MCH}$ and $\mathrm{MCHC}$ followed the same trend. They were highest for the birds in control diet and least in those in $\mathrm{BKB}$ based diet.

Virtually all the haematological values obtained in this study fall within the referral range (Adeyemi et al., 2000; Aeangwanich et al.,2004;Akandeet al., 2013;Antyev et al., 2017)Since haematological values are important indicators of health status of animals, and indispensable tools in the diagnosis, treatment and prognosis of many diseases, all the birds were sound health wise, notwithstanding the method of processing the kidney beans. However, based on haematological profile, kidney beans are best processed by sun drying, and boiling of kidney beans is the least option.

Again, the higher values of $\mathrm{RBC}$ and $\mathrm{Hb}$ found in birds in $\mathrm{CD}$ and SDKB based diets is an indication of increase in the rate of the oxygen carrying capacity of the blood. It also indicates that the nutrients were more adequately utilized by the birds. The lower values obtained in other birds could be ascribed to less preference of the feeds(Remi-Adewum et al.,2004). PCVvalues which were high in birds fed control and SDKB diets was as a result of the birds trying to meet up with the increase in metabolic actions taking place in their bodies (Ofongo and Ologhobo, 2007; Piotr Minias, 2015).There was a significant $(\mathrm{p}<0.05)$ difference in the mean corpuscular haemoglobin concentration (MCHC), mean corpuscular haemoglobin $(\mathrm{MCH})$ and mean cell volume $(\mathrm{MCV})$ of the birds fed the different diets containing the various test material. The values obtained for MCV, MCHC and $\mathrm{MCH}$ in all the test diets falls within the normal reference range for broiler birds as given by Aeangwanich et al. (2004) andAntyev et al. (2017), although the values obtained were significantly different, it indicates that there was no negative interaction between the energy and protein levels in the diets.There was also a significant $(p<0.05)$ difference in the white blood cell count obtained from the birds when fed the different dietary treatments .The values of white blood cell count obtained in all the diet was more than that given in the reference range for broilers by Aeanwanich et al. (2004) and Akandeet al. (2013).The elevated white blood cell in all the diets could be as a result of physiological adjustment against antigenic effects associated with the diets. The white blood cell is known to play an important role in antibody.

Table.4.Haematological parameters of finisher broilers fed control diet, sun dried (raw), dehulled and boiled kidney beans based diet

\begin{tabular}{|c|c|c|c|c|c|}
\hline Parameters & Treatment 1 & Treatment 2 & Treatment 3 & Treatment 4 & p-val. \\
\hline $\mathrm{Hb}(\mathrm{g} / \mathrm{dl})$ & $10.42 \pm 0.19^{b}$ & $11.06 \pm 0.12^{\mathrm{a}}$ & $10.05 \pm 0.04^{\mathrm{c}}$ & $8.51 \pm 0.09^{d}$ & 0.00 \\
\hline $\mathrm{RBC}\left(\mathrm{x} 10^{6} / \mathrm{mm}^{3}\right)$ & $7.46 \pm 0.09 a^{a}$ & $7.10 \pm 0.02 \mathrm{~b}$ & $5.40 \pm 0.08 \mathrm{c}$ & $3.00 \pm 0.05 \mathrm{~d}$ & 0.00 \\
\hline $\mathrm{WBC}\left(\mathrm{x} 10^{3} / \mathrm{mm}^{3}\right)$ & $5.63 \pm 0.26$ & $5.39 \pm 0.17^{\mathrm{ab}}$ & $5.10 \pm 0.03^{b c}$ & $4.82 \pm 0.07^{c}$ & 0.00 \\
\hline $\operatorname{PCV}(\%)$ & $35.56 \pm 0.28$ a & $31.99 \pm 0.04 \mathrm{~b}$ & $0.68 \pm 0.25^{c}$ & $26.32 \pm 0.07 \mathrm{~d}$ & 0.00 \\
\hline MCV (fl) & $32.43 \pm 0.24^{\mathrm{a}}$ & $31.42 \pm 0.11 \mathrm{~b}$ & $30.30 \pm 0.10^{\mathrm{c}}$ & $29.78 \pm 0.09 \mathrm{~d}$ & 0.00 \\
\hline $\mathrm{MCH}(\mathrm{pg})$ & $31.45 \pm 0.13^{a}$ & $28.06 \pm 0.03 \mathrm{~b}$ & $26.52 \pm 0.08^{c}$ & $22.07 \pm 0.03 \mathrm{~d}$ & 0.00 \\
\hline $\mathrm{MCHC}(\%)$ & $31.45 \pm 0.15^{\mathrm{a}}$ & $30.08 \pm 0.05 \mathrm{~b}$ & $25.16 \pm 0.15^{\mathrm{c}}$ & $23.25 \pm 0.05 \mathrm{~d}$ & 0.00 \\
\hline
\end{tabular}

Means bearing different superscripts in the same row are significantly different $(p<0.05)$

\section{Serum biochemistry}

Serum enzymes AST and ALT were significantly $(p<0.05)$ influenced by the dietary treatment as shown in Table 5. These serum biochemical components of animals have been reported to be positively correlated with the quality of the diet which animals were fed (Adeyemi et al., 2000).Control diet and SDKB based diet had the highest serum enzyme content.These enzymes are key enzymes needed in the biotransformation and detoxification of various toxicants (Akande et al., 2013). The increased activities of the hepatic transferase are indicative of increased catabolism of amino acids (Obikaonu et al., 2011).The serum urea can be used as a test of renal function and protein breakdown.

Birds fed boiled kidney beans had the highest urea content $(p<0.05)$. This implies that there was better digestion, utilization and absorption of protein in the diet containing the boiled kidney beans. . This agrees with the report by Obikaonuet al. (2011) andAntyev et al. (2017).The creatinine level was high in birds fed BKD based diet than in other birds, with birds fed control and SD diets having the lowest. High level of creatinine in the 
blood serum can be diagnosed as the possible increase in the tear and wear of muscles as the birds grow and carry out their metabolic activities. It could also imply that there is possible occurrence of renal damage since the amount of urea to be excreted by the bird has increased (Loggerenberg, 2007; Sadeghi and Pourreza, 2007; Antyev et al., 2017).

The serum total protein, globulin and albumin of the birds were significantly $(p<0.05)$ affected by the diets. The birds fed control and SDKD based diets had high values of the serum protein, globulin and albumin.Serum albumin and globulin content of blood depends on the availability of dietary protein. This means that the proteins of the Control and SDKB based diets were similarly available to the birds confirming the observation by Hoffenberg et al. (1966). Similarly, the cholesterol contents were higher in birds fed control and SDKB based diets than those in the other diets. However, this does not agree with the work of Sadeghi and Pourreza (2007) who said that the cholesterol level in the serum has a negative correlation with the fiber content of the animal's diet. The discrepancies might be as a result of the nature/ source of the fibre fed.

Table 5.Serum biochemical parameters of broiler birds fed sun dried (raw), dehulled and boiled kidney bean based diet

\begin{tabular}{|c|c|c|c|c|c|}
\hline Serum parameter & $\begin{array}{l}\text { Treatment } 1 \\
\text { CD }\end{array}$ & $\begin{array}{l}\text { Treatment } 2 \\
\text { SDKB }\end{array}$ & $\begin{array}{l}\text { Treatment } 3 \\
\text { DKB }\end{array}$ & $\begin{array}{l}\text { Treatment } 4 \\
\text { BKB }\end{array}$ & P- Value \\
\hline Total protein $(\mathrm{g} / \mathrm{dl})$ & $73.39 \pm 0.37^{\mathrm{a}}$ & $68.33 \pm 0.38^{\mathrm{b}}$ & $66.37 \pm 0.42^{c}$ & $60.51 \pm 0.30^{\mathrm{d}}$ & 0.00 \\
\hline Albumin $(\mathrm{g} / \mathrm{dl})$ & $24.74 \pm 0.22 \mathrm{a}^{\mathrm{a}}$ & $24.17 \pm 0.26 \mathrm{~b}$ & $23.22 \pm 0.22^{c}$ & $22.72 \pm 0.11 \mathrm{~d}$ & 0.00 \\
\hline Globulin $(\mathrm{g} / \mathrm{dl})$ & $48.62 \pm 0.30^{a}$ & $43.45 \pm 0.15 \mathrm{~b}$ & $42.16 \pm 0.23^{c}$ & $41.56 \pm 0.28^{d}$ & 0.00 \\
\hline Urea (mg/dl) & $3.05 \pm 0.42^{\mathrm{d}}$ & $3.49 \pm 0.15^{\mathrm{c}}$ & $3.65 \pm 0.19 \mathrm{~b}$ & $4.09 \pm 0.11^{\mathrm{a}}$ & 0.00 \\
\hline $\begin{array}{l}\text { Cholesterol } \\
(\mathrm{mg} / \mathrm{dl})\end{array}$ & $35.40 \pm 0.30^{a}$ & $34.52 \pm 0.21 \mathrm{~b}$ & $33.09 \pm 0.19^{c}$ & $28.53 \pm 0.18^{d}$ & 0.00 \\
\hline Creatinine (mg/dl) & $3.21 \pm 0.16^{\mathrm{d}}$ & $3.61 \pm 0.09^{c}$ & $6.00 \pm 0.05 \mathrm{~b}$ & $6.53 \pm 0.20$ & 0.00 \\
\hline Glucose (mg/dl) & $38.33 \pm 0.15^{a}$ & $35.39 \pm 0.27$ b & $32.29 \pm 0.28 \mathrm{c}$ & $28.48 \pm 0.17 \mathrm{~d}$ & .00 \\
\hline AST (IU/L) & $125.52 \pm 0.18 \quad$ a & $123.66 \pm 0.21^{b}$ & $116.51 \pm 0.30^{\mathrm{c}}$ & $117.31 \pm 0.13 \mathrm{~d}$ & 0.00 \\
\hline ALT (IU/L) & $29.66 \pm 0.21^{c}$ & $34.35 \pm 0.18$ a & $29.53 \pm 0.31 \mathrm{~d}$ & $30.17 \pm 0.19 b$ & 0.00 \\
\hline
\end{tabular}

Means bearing different superscripts in the same row are significantly different $(p<0.05)$

\section{CONCLUSION}

Based on the findings of this study, kidney beans can be used as an alternative source of protein in poultry diet by eithersun drying or dehulling or boiling the beans without any serious deleterious effect on the haematological and serum biochemical indices of the birds. However, sun drying the kidney bean is the best processing method followed by dehulling the beans.

\section{REFERENCES}

[1] Adeyemi, O.A., Fashina, and Balogun, M.O. (2000). Utilization of full-fat Jatropha seed in broiler diet: Effect on haematological parameters and blood chemistry. In:Proc $25^{\text {th }}$ Animal Conference Nig Soc Anim Pro. (NSAP).Umudike, pg.108-109.

[2] Aeangwanich W, Simarrakas S, Chinrasri O (2004). Haematological erythrocytes and serum biochemical value of the thaii indigenous chicken (Gallus domesticus) in North-Eastern Thailand. Songkalanakarian J. Sci. Technol., 26 (3):425-430.

[3] Akande, T.O., Odunsi, A.A., Rafiu, T.A., Olaniyi, C.O.and Binuomote, R.T. (2013). Growth and serological assessment of broiler chickens fed differently processed casto (Ricinus communis linn) kernel cake based diets. African Journal of Agricultural Research, 8(41): 5161-5169

[4] Antyev M, B. Yakubu, Y. H. Aliyara and R. J. Wafar (2017).Effects of Processing Methods of Jatropha curcas Seed Meal on Growth Performance and Blood Profile of Broiler Finisher Chickens. Asian Research Journal of Agriculture 4(4): 1-9 Available from:

https://www.researchgate.net/publication/317111285 Effects of Processing Methods of Jatropha curc as Seed Meal on Growth Performance and Bloo d Profile of Broiler Finisher Chickens [accessed Apr 18 2019].

[5] Enneking, D. (2011). The nutritive value of grass pea (Lathyrus sativus) and allied species. Their toxicity to animals and role of malnutrition in neurolathyrism.Food and Chemical Toxicity, 49:694-709.

[6] Hoffenberg .R. Black E and Black J.F. (1966). Serum metabolites. The Journal of clinical investigation. 
[7] Hussein, T., Vige, M., Animal, G. and Fikus. (2015). Effect of feeding processed kidney beans meal( Phaseolus vulgaris) by replacing soy bean meal on egg fertility and qualities of chicks of white leghorn hens.Journal of verternary Science and Technology. Retrived from doi: 10.4172/2157-7579-12-001

[8] Loggerenberg, M.V. (2007). Development and application of a small scale canning procedure for the evaluation of small white beans (Phaseolus vulgaris). (Doctoral Dissertation University of the free state, Bhempontein).

[9] Marzo.F., Alonso.R., Urdaneta .E., Arricibita, F.J., and Ibanez. F. (2002).Nutritional quality of extruded Kidney bean (Phaseolus vulgaris l. var-pinto) and its effects on growth and skeletal muscle nitrogen fractions in rats.Journal of Animal Science. Vol 80.pg 875-899.

[10] Mustapha, G.G., Igwebuike, J.U., Adamu, S.B., Kwari, I.D.J and Abba, Y. (2016). The effects of replacement levels of boiled and fermented castor seed meal on the haematological, serum biochemical and histopathology of broiler chickens. International Journal of Science and Nature, 7(3): 508-519.

[11] Obikaonu, H.O., Okoli,I.C., Opara, M.N., Okoro, U.M.O., Ogbuew,L.P., Etuk, E.B. and Udedibie, A.B.I.(2011). Haematological and serum biochemical indices of starter broilers fed neem (Azadirachta indica) leaf meal. Online Journal of Animal and Feed Research, 1(4): 150-154.

[12] Ofongo, S.T. and Ologhobo, A.D. (2007).Processed Kidney Bean (Phaseolus vulgaris) in Broiler feeding, performance characteristics. Conference of International Agricultural Research Development. p6.

[13] Preet .K. and Punes. D. (2000). Proximate composition phytic acid, polyphenols and digestibility of four brown cowpea varieties. International Journal of Food Science and Nutrition.51:189-193.

[14] Piotr Minias, (2015).The use of haemoglobin concentrations to assess physiological condition in birds: a review Conservation Physiology, Volume 3, Issue $1, \operatorname{cov} 007$, https://doi.org/10.1093/conphys/cov007

[15] Remi-Adewumi, B.D., E.O. Gyang and A.O. Osinowo, 2004. Abattoir survey of foreign body rumen impaction in small animals. Nig. Vet. J., 25(2): 32-38.Sandt et al. (2012)

[16] Sadeghi, G.H. and Pourreza, J. (2007). Serum proteins and some Biochemical parameters in broiler chickens fed with raw and treated Bitter vetch (Vicia evilia) seeds. Pakinstan Journal of Biological Sciences.10 (6): 977-981 